\title{
Oxidative stress and calcium dysregulation by palmitate in type 2 diabetes
}

\author{
Luong Dai Ly ${ }^{1,2,6}$, Shanhua $\mathrm{Xu}^{1,2,6}$, Seong-Kyung Choi ${ }^{1,6}$, Chae-Myeong $\mathrm{Ha}^{3}$, Themis Thoudam ${ }^{3}$, \\ Seung-Kuy Cha ${ }^{1,2}$, Andreas Wiederkehr ${ }^{4}$, Claes B Wollheim ${ }^{5}$, In-Kyu Lee ${ }^{3}$ and Kyu-Sang Park ${ }^{1,2}$
}

Free fatty acids (FFAs) are important substrates for mitochondrial oxidative metabolism and ATP synthesis but also cause serious stress to various tissues, contributing to the development of metabolic diseases. CD36 is a major mediator of cellular FFA uptake. Inside the cell, saturated FFAs are able to induce the production of cytosolic and mitochondrial reactive oxygen species (ROS), which can be prevented by co-exposure to unsaturated FFAs. There are close connections between oxidative stress and organellar $\mathrm{Ca}^{2+}$ homeostasis. Highly oxidative conditions induced by palmitate trigger aberrant endoplasmic reticulum (ER) $\mathrm{Ca}^{2+}$ release and thereby deplete ER $\mathrm{Ca}^{2+}$ stores. The resulting ER Ca ${ }^{2+}$ deficiency impairs chaperones of the protein folding machinery, leading to the accumulation of misfolded proteins. This ER stress may further aggravate oxidative stress by augmenting ER ROS production. Secondary to ER $\mathrm{Ca}^{2+}$ release, cytosolic and mitochondrial matrix $\mathrm{Ca}^{2+}$ concentrations can also be altered. In addition, plasmalemmal ion channels operated by ER $\mathrm{Ca}^{2+}$ depletion mediate persistent $\mathrm{Ca}^{2+}$ influx, further impairing cytosolic and mitochondrial $\mathrm{Ca}^{2+}$ homeostasis. Mitochondrial $\mathrm{Ca}^{2+}$ overload causes superoxide production and functional impairment, culminating in apoptosis. This vicious cycle of lipotoxicity occurs in multiple tissues, resulting in $\beta$-cell failure and insulin resistance in target tissues, and further aggravates diabetic complications.

Experimental \& Molecular Medicine (2017) 49, e291; doi:10.1038/emm.2016.157; published online 3 February 2017

\section{INTRODUCTION}

Free fatty acids (FFAs) are important sources of fuel required for efficient cellular energy production. FFAs enter mitochondria via carnitine palmitoyltransferase 1 (CPT1) and undergo $\beta$-oxidation to generate acetyl-CoA, which serves as a substrate for the Krebs cycle. Fatty acid metabolism generates reducing equivalents used by the electron transport chain (ETC) for ATP synthesis. ${ }^{1}$ Increased $\beta$-oxidation attenuates further mitochondrial FFA uptake through the formation of malonyl CoA, an inhibitor of CPT1. Excess FFA critically induces reactive oxygen species (ROS) generation, resulting in lipotoxicity associated with ER stress, calcium dysregulation, mitochondrial dysfunction and cell death.

Palmitate, stearate and oleate are the most abundant FFAs, accounting for $70-80 \%$ of total plasma FFAs. ${ }^{2}$ FFA concentrations in patients with type 2 diabetes are significantly higher than in healthy subjects. ${ }^{3,4}$ Compared with normal subjects, rates of palmitate appearance in plasma are 1.5- and 3-fold higher in type 2 diabetic individuals during nocturnal and postprandial states, respectively. ${ }^{4}$ In the Paris Prospective Study, increased plasma FFA concentration and decreased 2-h plasma insulin levels are considered to be independent predictors of type 2 diabetes in subjects with a history of impaired glucose tolerance. Among impaired glucose tolerance subjects who develop type 2 diabetes, $78 \%$ are in the highest tertile of fasting FFA concentrations. It has been suggested that lipotoxicity is associated with uncompensated insulin secretion in patients with insulin resistance, leading to overt type 2 diabetes. ${ }^{5}$

In this review, we summarize the molecular mechanisms leading to palmitate-induced toxicity in type 2 diabetes, including sources of ROS generation and $\mathrm{Ca}^{2+}$-mediated pathogenic changes. These mechanisms show harmful cross-interactions. Endoplasmic reticulum (ER) $\mathrm{Ca}^{2+}$ release due to palmitate-induced oxidative stress results in cytosolic and mitochondrial $\mathrm{Ca}^{2+}$ overload, which may further accelerate

\footnotetext{
${ }^{1}$ Department of Physiology, Institute of Lifestyle Medicine, Yonsei University Wonju College of Medicine, Gangwon-Do, Republic of Korea; ${ }^{2}$ Mitohormesis Translational Research Center, Yonsei University Wonju College of Medicine, Wonju, Republic of Korea; ${ }^{3}$ Department of Internal Medicine, Kyungpook National University Hospital, Daegu, Korea; ${ }^{4}$ Mitochondrial Function, Nestlé Institute of Health Sciences, Lausanne, Switzerland and ${ }^{5}$ Department of Cell Physiology and Metabolism, University of Geneva, Geneva, Switzerland

${ }^{6}$ These authors contributed equally to this work.

Correspondence: Professor K-S Park, Department of Physiology, Institute of Lifestyle Medicine, Yonsei University, Wonju College of Medicine, Ilsan-ro 20, Wonju, Gangwon-Do 26426, Republic of Korea.

E-mail: qsang@yonsei.ac.kr
}

Received 22 July 2016; revised 7 October 2016; accepted 16 October 2016 
ROS generation from mitochondria and facilitate permeability transition (PT) pore opening. The activation of store-operated $\mathrm{Ca}^{2+}$ (SOC) entry triggered by ER $\mathrm{Ca}^{2+}$ depletion augments the persistent $\mathrm{Ca}^{2+}$ load. The interruption of such vicious cycles of ROS formation and $\mathrm{Ca}^{2+}$ dysregulation may be a good therapeutic target for the prevention and treatment of metabolic diseases related to lipotoxicity.

\section{CD36: FATTY ACID TRANSPORTER OR RECEPTOR?}

CD36 is an $88-\mathrm{kDa}$, ditopic, heavily N-linked glycosylated transmembrane protein that is also known as fatty acid translocase (FAT). ${ }^{6}$ CD36 is abundantly expressed in tissues with a high capacity for fatty acid metabolism (for example, adipose tissue, cardiac and skeletal muscles) ${ }^{6-8}$ Other cells and tissues including liver, ${ }^{9}$ endothelial cells, ${ }^{10}$ monocytes, macrophages ${ }^{11,12}$ pancreatic $\beta$-cells ${ }^{13}$ and podocytes ${ }^{14}$ also express CD36.

Muscle-specific over-expression of CD36 enhances FFA uptake and thus decreases plasma triglyceride and fatty acids levels. ${ }^{15}$ Conversely, FFA uptake is impaired in CD36 null mice with high plasma concentrations of cholesterol and triglyceride. ${ }^{16}$ CD36 expression is low in normal hepatocytes and does not have a significant role in FFA uptake. ${ }^{8,9,17-19}$ The Pro90Ser CD36 mutation in humans perturbs the FFA uptake of muscle and adipose tissue, but hepatic uptake is not affected under suppressed or slightly increased concentrations of palmitate. ${ }^{18}$ Consistently, hepatic FFA uptake is not disturbed in CD36 knockout mice. ${ }^{8}$ Under a high-fat diet or in hepatic steatosis, CD36 is highly inducible by activation of nuclear receptors, including liver $\mathrm{X}$ receptor, pregnane $\mathrm{X}$ receptor, peroxisome proliferator-activated receptor $\gamma$ and the aryl hydrocarbon receptor. ${ }^{9,17,19}$ However, controversies arise concerning the impact of CD36 on fatty liver disease. Hepatocyte-specific CD36 disruption significantly reduces hepatic triacylglycerol, diacylglycerol (DAG) and cholesterol ester content and improves insulin sensitivity when a high-fat diet is consumed. ${ }^{19}$ However, liver-specific CD36 overexpression attenuated hepatic steatosis and insulin resistance in another study with transgenic mice. ${ }^{17,19}$

In addition to its role in FFA transport, CD36 has an important role in signal transduction through the activation of non-receptor tyrosine kinases of the Src family, including Fyn and Lyn. ${ }^{20,21}$ The binding of long chain (LC)-FFAs to CD36 stimulates the tyrosine phosphorylation of downstream proteins, inducing pro-inflammatory and atherogenic responses associated with diabetes, atherosclerosis, thrombosis, and Alzheimer disease. ${ }^{20}$ Ligand binding to CD36 also stimulates phospholipase $\mathrm{C}$ (PLC) and, as a consequence, $\mathrm{IP}_{3}$-mediated ER $\mathrm{Ca}^{2+}$ release. This signaling pathway contributes, for example, to the sensing of LC-FFA in taste buds. ${ }^{22}$ In addition, CD36 stimulates SOC influx. The associated increase in $\mathrm{Ca}^{2+}$ activates $\mathrm{Ca}^{2+}$-dependent phospholipase $\mathrm{A} 2$ and prostaglandin synthesis involved in inflammatory responses. ${ }^{21}$

Interestingly, CD36 is upregulated in response to high glucose in insulin-secreting cells and in patients with diabetic nephropathy. Such regulation of CD36 expression may lead to the exacerbation of glucolipotoxicity via increased FFA uptake. $^{23,24}$ In insulinoma cells, CD36 induction increases the uptake of FFA, leading to the blunting of the functional interplay between glucose and lipids in insulin secretion as a consequence of impaired oxidative metabolism. ${ }^{25}$ The disruption of the CD36 gene, however, protects from obesityassociated steatosis and insulin resistance. ${ }^{26}$ In diabetic animals, a lack of CD36 attenuates NADPH oxidase (NOX)-dependent ROS generation. Moreover, the targeted disruption of CD36 in macrophages shows protective action against atherosclerosis. ${ }^{27}$ Therefore, CD36 could be a therapeutic target for the treatment of metabolic dysfunction worsened by dyslipidemia.

Sulfo-N-succinimidyl derivatives have been developed as selective inhibitors for CD36. ${ }^{28,29}$ Preincubation with a CD36 inhibitor prevents saturated FFA-induced ROS production and cytotoxicity. ${ }^{24,30}$ Sulfo-N-succinimidyl derivatives also inhibit oxidized low-density lipoprotein (oxLDL) uptake in macrophages. ${ }^{21}$ Recently, Souza et al. ${ }^{31}$ demonstrated that the $5 \mathrm{~A}$ peptide antagonizes oxLDL binding to CD36, inhibiting inflammation and oxidative stress in vascular tissues. The 5A peptide, through its inhibition of $\mathrm{CD} 36$, also reduces glomerular injury and tubule-interstitial fibrosis in animal models of chronic kidney disease. ${ }^{31}$

\section{OXIDATIVE STRESS INDUCED BY FATTY ACIDS}

Reactive oxygen species are essential signaling molecules that regulate physiological cell functions. ${ }^{32}$ However, the overproduction of ROS in pathologic conditions has detrimental consequences, causing organellar stress, injury and cell death. ${ }^{33,34}$ Palmitate is a potent inducer of ROS in a number of cell types, including pancreatic $\beta$ cells, ${ }^{35-37}$ cardiomyocytes, ${ }^{34,38}$ vascular smooth muscle cells, ${ }^{39}$ endothelial cells, ${ }^{40}$ skeletal muscle cells ${ }^{41}$ glomerular podocytes, ${ }^{30}$ hepatocytes ${ }^{42}$ and adipocytes. ${ }^{43} \mathrm{CD} 36$ appears to be required for fatty acidinduced ROS production due to the fact that the knockdown of CD36 prevents palmitate-dependent oxidative stress. ${ }^{23}$

Increased mitochondrial fatty acid oxidation has been proposed as the main process leading to ROS generation in lipotoxicity (Figure 1). The oxidation of palmitate delivers excess electrons to the ETC, which thus causes superoxide overproduction. ${ }^{44-46}$ There are, however, conflicting data in the literature showing that the acceleration of $\beta$-oxidation actually relieves oxidative stress, and the inhibition of mitochondrial fatty acid uptake aggravates ROS production. ${ }^{47,48}$ The molecular mechanisms for cellular ROS generation by palmitate, therefore, remain to be fully elucidated.

Palmitate-induced superoxide cannot be fully eliminated by the addition of the complex III inhibitor antimycin A, revealing that ROS are also generated through sources other than the ETC. ${ }^{44}$ In chondrocytes, a mixture of oleate and palmitate enhances ROS production and induces cell apoptosis, mainly by upregulating the protein levels of NOX $4 .{ }^{49}$ Notably, NOX4 is expressed in mitochondria and contributes to mitochondrial ROS production. ${ }^{50,51} \mathrm{~A}$ recent study suggests that the activation of protein kinase $\mathrm{C} \alpha(\mathrm{PKC} \alpha)$ by palmitate increases ROS production through NOX2 upregulation in cardiomyocytes. ${ }^{38}$ 


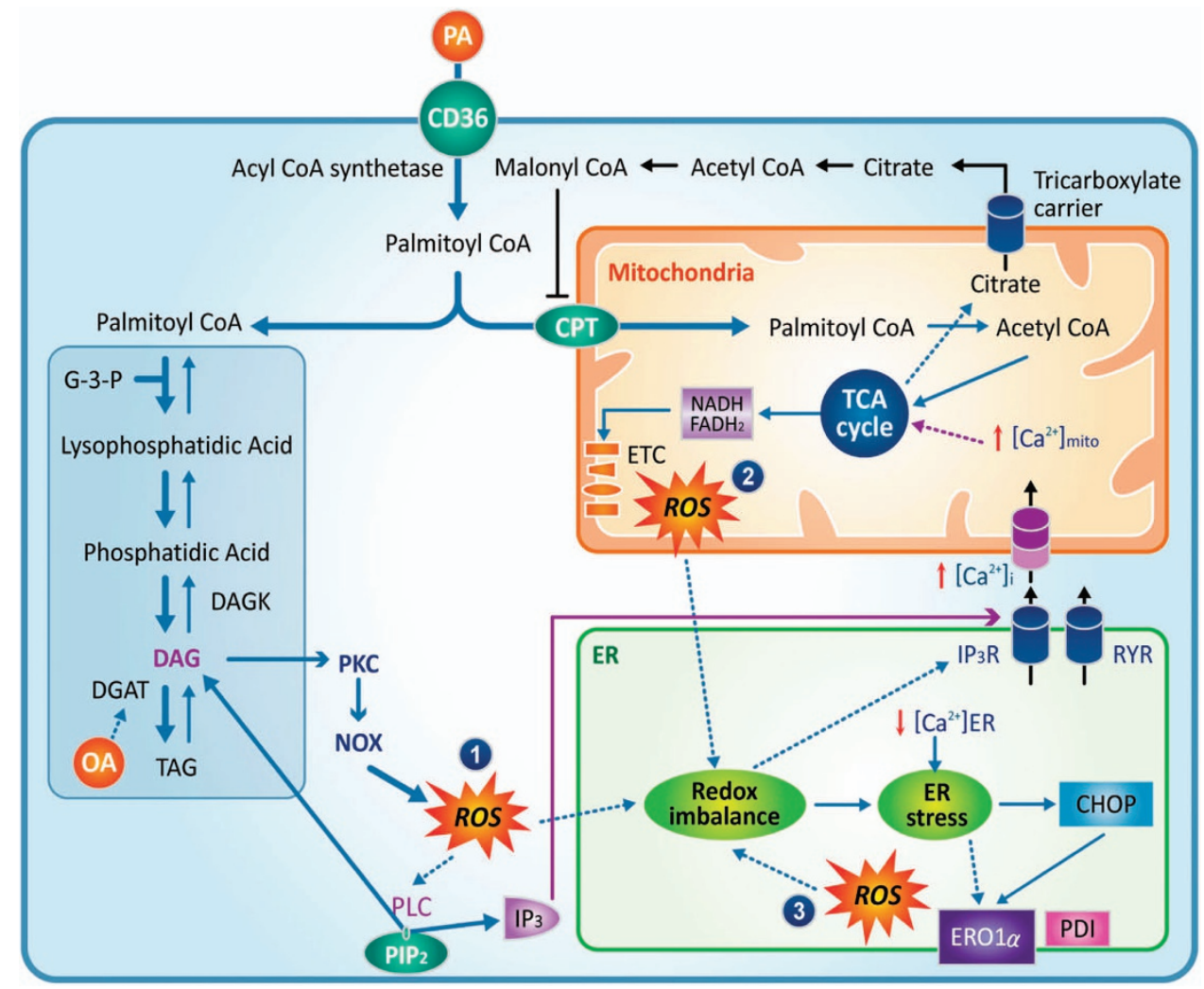

Figure 1 Palmitate induces ROS overproduction. (1) Increased $\beta$-oxidation, (2) DAG-PKC-NOX, (3) CHOP-ERO1 $\alpha$ and PDI under ER stress. ROS produced by palmitate triggers PLC activation, $\mathrm{ER} \mathrm{Ca}^{2+}$ release, ER stress and mitochondrial dysfunction, which, in turn, aggravate ROS generation. CHOP, CCAAT-enhancer-binding protein homologous protein; DAG, diacylglycerol; ERO1 $\alpha$, ER oxidoreductin 1 alpha; NOX, NADPH oxidase; PDI, protein disulfide isomerase; PKC, protein kinase C; PLC, phospholipase C; ROS, reactive oxygen species.

An upstream stimulus of PKC is DAG, which is produced either in a membrane-delimited manner with $\mathrm{G}_{\mathrm{q} / 11^{-} \text {-coupled }}$ PLC or by enzymatic synthesis from phosphatidic acid. Palmitate increases DAG in a number of cell types. ${ }^{52-54}$ The formation of this signaling molecule may be responsible for palmitate-induced PKC activation and ROS generation (Figure 1). Moreover, there is crosstalk between mitochondria and the NADPH oxidase system via feed-forward amplification of ROS production..$^{55}$ The involvement of ER oxidoreductin 1 alpha $(\mathrm{ERO} 1 \alpha)$ and disulfide isomerase during ER stress, as well as ER-mitochondrial $\mathrm{Ca}^{2+}$ dysregulation in ROS overproduction, will be discussed later in this review.

Unlike palmitate, oleate is an unsaturated fatty acid with a cis double bond at position 9. Oleate may stimulate ROS generation but may also protect from oxidative stress. Oleate has been reported to increase intracellular $\mathrm{H}_{2} \mathrm{O}_{2}$ production in rat smooth muscle cells ${ }^{56}$ pancreatic $\beta$-cells, ${ }^{57}$ and human hepatoma HepG2 cells..$^{58}$ Other studies, however, reported no effect of oleate on ROS generation in smooth muscle cells from the human coronary artery ${ }^{59}$ or Chang liver cells..$^{60}$ Oleate is even able to attenuate or abolish palmitate-induced ROS synthesis when the two fatty acids are used in combination. ${ }^{30,61}$ Despite apparently conflicting data, there is some convincing evidence that oleate does not increase mitochondrial ROS level when employing a technique specifically detecting mitochondrial
ROS. ${ }^{38,61}$ Reduced ROS generation in the presence of oleate is correlated with a protective effect of unsaturated FFAs on ER stress and cytotoxicity.

\section{PALMITATE INDUCES ER STRESS}

Approximately one-third of all newly synthesized proteins are imported into the ER. ${ }^{62}$ Proteins trafficking through the ER undergo post-translational processing modifications, including glycosylation and chaperone-assisted protein folding. The oxidative folding process, especially the generation of disulfide bonds, generates a large amount of ROS. ${ }^{63}$ Therefore, redox homeostasis is vital to maintain ER folding capacity. Palmitateinduced ROS formation impairs ER redox status and leads to the accumulation of misfolded or unfolded proteins. ${ }^{64,65}$ The associated excess workload beyond the protein folding capacity of the ER activates the unfolded protein response in an attempt to reestablish normal ER function. ${ }^{66}$ Unfolded protein response -dependent signaling is initiated by three ER transmembrane proteins: inositol-requiring protein $1 \alpha$ (IRE1 $\alpha)$, protein kinase RNA-like endoplasmic reticulum kinase (PERK) and activating transcription factor 6 (ATF6). These stress sensors normally bind to a luminal ER chaperone called the binding immunoglobulin protein (BiP or GRP78). BiP has a high affinity for unfolded proteins. As unfolded proteins accumulate in the ER lumen, BiPs detach from the stress sensors activating downstream signaling, leading to three main outcomes: 
(1) the overall attenuation of translation, with the simultaneous

(2) promotion of the translation of ER chaperones and

(3) the restoration of the ER-associated degradation (ERAD) system. ${ }^{67,68}$ If the stress is too severe to be resolved by the unfolded protein response, the cell triggers a death program to be eliminated.

The condensation of palmitoyl-CoA, the activated form of palmitate and serine, is the first step in the biosynthesis of ceramide, which is catalyzed by serine palmitoyltransferase. Ceramide activates protein phosphatase $2 \mathrm{~A}$ and $\mathrm{PKC}$, both of which can inhibit Akt activation, leading to insulin resistance in skeletal muscle and adipose tissue. ${ }^{69,70}$ This pathogenic process activates pro-apoptotic signaling and cytochrome $c$ release from mitochondrial inter-membrane space. ${ }^{71}$ Ceramide also inhibits mitochondrial beta-oxidation, which aggravates palmitateinduced lipotoxicity. ${ }^{72}$ Intriguingly, ceramide induces the loss of the ER calcium pool and ER stress. The inhibition of the sarco/endoplasmic reticulum $\mathrm{Ca}^{2+}$ ATPase (SERCA) by ceramide has been suggested as the main mechanism of ER calcium depletion. ${ }^{73}$

Unlike palmitate, oleate does not cause a significant ER stress response. ${ }^{30,38,61}$ Moreover, oleate prevents palmitate-induced ER stress, c-Jun N-terminal kinase (JNK) activation and cell death, ${ }^{74,75}$ all of which are consistent with reduced ROS generation. A key difference between the two fatty acids is that oleate, but not palmitate, activates diacylglycerol acyl transferase (DGAT). The stimulation of DGAT lessens DAG accumulation by converting it to triacylglycerol. ${ }^{76-78}$ Using ${ }^{3} \mathrm{H}$-labeled palmitate, it was shown that oleate attenuates palmitate-induced DAG formation and instead leads to the preferential accumulation of triacylglycerol. ${ }^{79}$ Oleate promotes the mitochondrial oxidation of palmitate by increasing CPT1 expression. This mechanism contributes to diminished total palmitate and palmitate-derived toxic metabolites. ${ }^{78}$

The ER stress response could be a therapeutic target to prevent palmitate-induced lipotoxicity. There have been attempts to tackle diseases of protein misfolding, such as cystic fibrosis, $\alpha 1$ antitrypsin deficiency, Alzheimer disease and type 2 diabetes, using the chemical chaperone 4-phenylbutyric acid. ${ }^{80-83}$ Taurine-conjugated ursodeoxycholic acid (TUDCA) has also been tested as a chaperone to protect hepatocytes from palmitate-induced ER stress and apoptosis. ${ }^{84}$ Salubrinal, a selective chemical inhibitor of eIF $2 \alpha$ phosphatase, was introduced to prevent ER stress. ${ }^{85}$ Further studies revealed, however, that salubrinal treatment shows deleterious effects in pancreatic $\beta$-cells and other cell types. ${ }^{86,87}$

Several studies have demonstrated that knockdown of ER stress proteins (for example, CCAAT-enhancer-binding protein

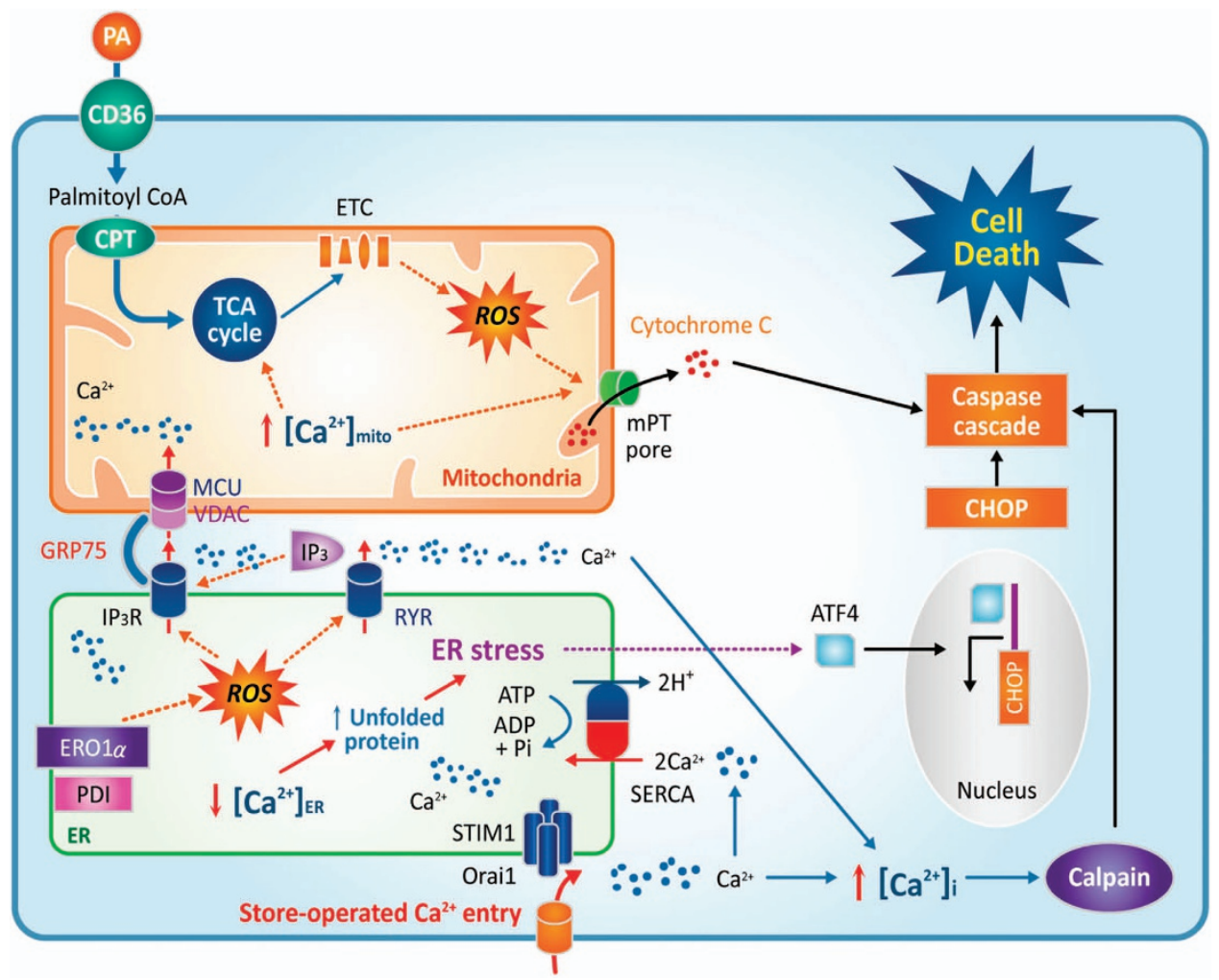

Figure 2 Palmitate disturbs intracellular $\mathrm{Ca}^{2+}$ homeostasis. ROS activate $\mathrm{IP}_{3} \mathrm{R}$ and RYR, which release $\mathrm{Ca}^{2+}$ from the ER. The deprivation of $\mathrm{ER} \mathrm{Ca}{ }^{2+}$ leads to ER stress and $\mathrm{CHOP}$ upregulation. $\mathrm{Ca}^{2+}$ is transported into mitochondria through a specialized structure composed of $I_{3} R, V D A C, M C U$ and GRP75. Excessive $\mathrm{Ca}^{2+}$ in mitochondria leads to cytochrome $c$ release. SOC entry triggered by ER Ca ${ }^{2+}$ depletion elicits the persistent influx of $\mathrm{Ca}^{2+}$ into cytosol and mitochondria. High intracellular calcium activates calpain signaling. Cytochrome $c$, $\mathrm{CHOP}$ and calpain all provoke caspase activation and cell death. CHOP, CCAAT-enhancer-binding protein homologous protein; GRP75, $75 \mathrm{kDa}$ glucose-regulated protein; $\mathrm{MCU}$, mitochondrial $\mathrm{Ca}^{2+}$ uniporter; ROS, reactive oxygen species; SOC, store-operated $\mathrm{Ca}^{2+}$; VDAC, voltage-dependent anion channel. 
homologous protein $(\mathrm{CHOP}))$ has protective effects on palmitate-induced apoptosis in insulin-secreting cells, ${ }^{68,88}$ podocytes $^{75}$ and other cell types. ${ }^{84,89}$ However, CHOP knockout mice suffer from steatohepatitis and fibrosis due to the pro-inflammatory actions of CHOP-deleted macrophages in the liver. Therefore, more research is required to find better interventions to prevent palmitate-induced ER stress without serious adverse events.

\section{ER CALCIUM DEPLETION BY PALMITATE}

Luminal ER $\mathrm{Ca}^{2+}$ concentration is particularly important for protein folding. High levels of $\mathrm{Ca}^{2+}$ in the ER lumen $(>400 \mu \mathrm{M})$ are required for interactions among ER chaperones and between chaperones and unfolded proteins. ${ }^{66}$ SERCA maintains high $\mathrm{ER} \mathrm{Ca}^{2+}$ concentrations. A chronic reduction of $\mathrm{ER} \mathrm{Ca}^{2+}$ stores elicits the accumulation of unfolded or misfolded proteins and initiates an ER stress response (Figure 2). ${ }^{66,90}$ Exposure to thapsigargin, an inhibitor of SERCA, is applied to induce ER stress experimentally by depleting the $\mathrm{ER} \mathrm{Ca}^{2+}$ stores. Palmitate-induced ER stress is also associated with a sustained reduction of the $\mathrm{ER} \mathrm{Ca}^{2+}$ pool, which has been demonstrated directly through cytosolic and $\mathrm{ER} \mathrm{Ca}^{2+}$ measurements. ${ }^{30,68,88,91} \mathrm{ER} \mathrm{Ca}^{2+}$ loss caused by FFA triggers the unfolded protein response to rescue cells from misfolded protein overload or programmed cell death. ${ }^{92}$

ER proteome analysis in the liver of ob/ob mice shows a fundamental shift in ER function in obesity from protein synthesis to lipid synthesis and metabolism..$^{93}$ One important factor inducing ER calcium depletion in obesity is the increased phosphatidylcholine/phosphatidylethanolamine ratio, which disrupts ER calcium refilling capacity by inhibiting SERCA activity. This regulation did not occur at the level of expression, as the SERCA protein was slightly more abundant in ob/ob mice compared to lean mice. The suppression of phosphatidylcholine synthesis from phosphatidylethanolamine normalized the phosphatidylcholine / phosphatidylethanolamine ratio, protected against ER stress and improved systemic glucose homeostasis.

The accumulation of misfolded proteins causes ROS generation from the oxidative folding machineries in the ER and mitochondria. ${ }^{94}$ Defective disulfide bond formation depletes glutathione in the ER and produces oxygen radicals via $\mathrm{ERO} 1 \alpha$ and protein disulfide isomerase. ${ }^{63}$ Intriguingly, ROS produced by ERO1 $\alpha$ activates type $1 \mathrm{IP}_{3}$ receptors $\left(\mathrm{IP}_{3} \mathrm{R}\right)$ and stimulates ER Ca ${ }^{2+}$ release. ${ }^{95}$ Consequent ER $\mathrm{Ca}^{2+}$ loss further deteriorates the protein-folding process and augments ROS generation. Furthermore, prolonged ER stress increases $\mathrm{CHOP}$ expression, which upregulates $\mathrm{ERO} 1 \alpha$, causing additional oxidative stress. This positive feedback mechanism amplifies oxidation-triggered $\mathrm{IP}_{3} \mathrm{R}$ activation and $\mathrm{ER} \mathrm{Ca}^{2+}$ release (Figure 1). Blocking this vicious cycle between ER ROS formation and $\mathrm{ER} \mathrm{Ca}^{2+}$ release could be a pertinent therapeutic strategy. In support of this approach, we observed that palmitate-induced $\mathrm{ER} \mathrm{Ca}^{2+}$ loss was prevented by both ROS scavengers or the inhibition of $\mathrm{IP}_{3}$ generation. ${ }^{30}$
It is noteworthy that $\mathrm{H}_{2} \mathrm{O}_{2}$-mediated oxidative stress can activate PLC $\gamma$ and generate $\mathrm{IP}_{3}$ and DAG in astrocytes and lung endothelial cells. ${ }^{96,97}$ Consistent with these findings, PLC activation was observed in podocytes treated with either palmitate or $\mathrm{H}_{2} \mathrm{O}_{2}$. Pretreatment with a PLC inhibitor attenuated palmitate-induced $\mathrm{ER} \mathrm{Ca}^{2+}$ loss, suggesting that $\mathrm{IP}_{3}$ generation from phosphatidylinositol 4,5-bisphosphate $\left(\mathrm{PIP}_{2}\right)$ contributes to $\mathrm{ER} \mathrm{Ca}^{2+}$ release via the $\mathrm{IP}_{3} \mathrm{R}^{30}$ In addition, DAG, the other signaling molecule produced by PLC activity, may also participate in palmitate-dependent ER $\mathrm{Ca}^{2+}$ loss. This hypothesis was supported by experimental evidence showing that palmitate-induced $\mathrm{ER} \mathrm{Ca}^{2+}$ depletion and ER stress were surprisingly augmented by treatment with a DAG kinase blocker, leading to DAG accumulation..$^{30}$ DAG accumulation activates PKC $8 .{ }^{74}$ PKC activity upregulates NOX (Figure 1), and more ROS are thus generated, as discussed earlier, leading to further $\mathrm{ER} \mathrm{Ca}^{2+}$ loss. The inhibition of PKC blunted the effect of palmitate on $\mathrm{ER} \mathrm{Ca}^{2+}$, suggesting a critical pathogenic role for DAG-mediated PKC activation. ${ }^{30}$ We propose a synergistic stimulation of $\mathrm{Ca}^{2+}$ release from the ER by $\mathrm{IP}_{3}$ and DAG, although further detailed studies are required to substantiate our working model.

\section{PALMITATE DISTURBS INTRACELLULAR CALCIUM HOMEOSTASIS}

Plasma membrane $\mathrm{Ca}^{2+}$ ATPase (PMCA) and SERCA establish 1000- to 10000 -fold change gradients of $\mathrm{Ca}^{2+}$ concentrations across the plasma membrane and the ER membrane. ${ }^{90}$ Therefore, inappropriate and uncontrolled cytosolic $\mathrm{Ca}^{2+}$ increases that result from $\mathrm{Ca}^{2+}$ influx from the extracellular space or release from the ER are a burden for the cell as it tries to maintain intracellular $\mathrm{Ca}^{2+}$ homeostasis. $\mathrm{Ca}^{2+}$ stress may initiate pathogenic processes such as calpain-mediated cell death. In $\beta$-cells, for instance, it was observed that palmitateinduced $\mathrm{ER} \mathrm{Ca}^{2+}$ release activates the calcium-dependent pro-apoptotic protease calpain-2.92

$\mathrm{Ca}^{2+}$ release from the ER participates in cell death mechanisms. The luminal $\mathrm{ER} \mathrm{Ca}^{2+}$ level is an important factor determining susceptibility to apoptosis triggered by different kinds of proapoptotic stimuli, including ceramides and arachidonic acid.98,99 Recent discoveries support these observations by revealing a role for ER-mitochondrial contacts, known as the mitochondria-associated ER membrane (MAM) in apoptosis (Figure 2). MAMs are specialized subcompartments of the ER where the distance between the ER and the mitochondrial membranes is $<25 \mathrm{~nm} .{ }^{100}$ MAMs have been reported as either larger or tighter in diabetic mice on a high-fat diet. ${ }^{101,102}$ The physical contact points between the ER and mitochondria are enriched for specific membrane proteins such as the $\mathrm{IP}_{3}$ receptor, the voltage-dependent anion channel and the mitochondrial $\mathrm{Ca}^{2+}$ uniporter (MCU). Additional adaptor proteins, including GRP75, are also required to establish high capacity $\mathrm{Ca}^{2+}$ transfer from the ER to the mitochondria. ${ }^{103}$ The increased density of MAMs in the cells of animals fed a high-fat diet may aggravate $\mathrm{ER} \mathrm{Ca}^{2+}$ depletion 
and mitochondrial $\mathrm{Ca}^{2+}$ overload, although this hypothesis requires further experimentation. ${ }^{104}$

The activation of $\mathrm{Ca}^{2+}$ signals via PLC-mediated $\mathrm{IP}_{3}$ generation depletes $\mathrm{ER} \mathrm{Ca}^{2+}$ and may thus have a negative impact on ER function and cell survival. ${ }^{90}$ To prevent this pathogenic consequence, there is an innate response to refill the $\mathrm{ER} \mathrm{Ca}^{2+}$ reservoir. In the ER membrane, the stromal interaction molecule (STIM), a transmembrane protein with luminal EF hands, senses $\mathrm{ER} \mathrm{Ca}^{2+}$ levels. A decrease in $\mathrm{ER} \mathrm{Ca}^{2+}$ leads to STIM translocation to the plasma membrane-ER junctions. In these sub-plasma membrane areas, STIM proteins oligomerize to form clusters to recruit Orail, a plasmalemmal $\mathrm{Ca}^{2+}$ channel. Orail mediates SOC entry until $\mathrm{ER} \mathrm{Ca}^{2+}$ stores are refilled, at which point STIM oligomers again become dispersed. Notably, palmitate-treated cells maintain STIM1 oligomerization, signifying that $\mathrm{ER} \mathrm{Ca}^{2+}$ release and depletion of stores persist. ${ }^{30}$ Upon extracellular $\mathrm{Ca}^{2+}$ addition, palmitatetreated cells show strong and sustained increases in cytosolic $\mathrm{Ca}^{2+}$, whereas there is a negligible influence on $\mathrm{Ca}^{2+}$ influx in control cells (Figure 2). ${ }^{30}$ This evidence suggests that $\mathrm{ER} \mathrm{Ca}^{2+}$ depletion by palmitate induces sustained SOC entry, which may raise cytosolic and mitochondrial $\mathrm{Ca}^{2+}$ to an intolerable level. Low extracellular $\mathrm{Ca}^{2+}$ conditions protect against palmitate-induced cytotoxicity, suggesting that SOC contributes to the harmful effects of palmitate. ${ }^{105}$ It should be noted that $\mathrm{Ca}^{2+}$ influx via SOC entry is essential for physiological process such as immune cell activation. Moreover, there have been no reports of a truly selective SOC inhibitor until now. Nevertheless, we suggest that the prevention of sustained SOC activation could be a candidate for therapeutic targets to prevent lipotoxicity.

\section{MITOCHONDRIAL DYSFUNCTION BY PALMITATE}

Mitochondria have an essential role in energy metabolism, biosynthetic processes, $\mathrm{Ca}^{2+}$ homeostasis and the integration of apoptotic signals. ${ }^{106,107} \mathrm{Ca}^{2+}$ in the mitochondrial matrix and extramitochondrial locations modulates mitochondrial functions, including intermediary metabolism and ATP synthesis. Mitochondrial $\mathrm{Ca}^{2+}$ activates pyruvate dehydrogenase, Krebs cycle activity, mitochondrial transporters, and ATP synthase. ${ }^{108-110} \mathrm{MCU}$ is the main molecule responsible for mitochondrial $\mathrm{Ca}^{2+}$ uptake and the activation of mitochondrial metabolism. ${ }^{111,112}$ Unexpectedly, no obvious phenotype was initially observed in mice lacking MCU. ${ }^{113}$ In animals with a cardiac muscle-specific deletion, however, MCU deficiency induces defects in acute metabolic stimulation and protects against ischemia-reperfusion injury. ${ }^{114}$ Local increases in cytosolic $\mathrm{Ca}^{2+}$ arrest the movement of mitochondria, allowing the organelle to efficiently take up and sequester $\mathrm{Ca}^{2+}$ into its matrix to stimulate mitochondrial energetics. ${ }^{15}$ Excess mitochondrial $\mathrm{Ca}^{2+}$ uptake, in contrast, induces mitochondrial permeability transition pore opening, followed by cytochrome $c$ release and apoptotic cell death (Figure 2). ${ }^{116}$

Accumulating evidence suggests that human subjects with obesity or insulin resistance exhibit reduced oxygen consumption rates, decreased expression of mitochondrial proteins, and impaired ATP synthesis. ${ }^{117,118}$ Mitochondrial dysfunction decreases $\beta$-oxidation and may elevate plasma FFA concentration, thereby aggravating lipotoxicity. The supplementation of tricarboxylic acid cycle substrates to facilitate mitochondrial FFA metabolism rescues lipotoxicity in insulin-secreting cells. ${ }^{47,119}$ However, excessive FFA in mitochondria stimulates superoxide generation from the ETC, leading to cytotoxicity. ${ }^{44}$

Mitochondria are dynamic organelles that undergo continuous fusion and fission. ${ }^{120}$ During this process, dysfunctional mitochondria are separated and degraded by mitophagy, which acts as a quality control mechanism. ${ }^{121}$ Palmitate induces mitochondrial depolarization, morphodynamic fragmentation and impaired ATP synthesis. ${ }^{30}$ Furthermore, palmitate suppresses autophagic activity, which may increase the proportion of dysfunctional mitochondria. Defective fission allows mitochondria to become more elongated but also more susceptible to glucolipotoxicity. ${ }^{121,122}$ The deterioration of mitochondrial function induces PT pore opening followed by caspase activation and apoptosis. The major known stimuli for PT pore opening are oxidative stress and matrix $\mathrm{Ca}^{2+}$ overload, both of which are observed during palmitate overload (Figure 2). Mitochondrial antioxidants effectively protect from palmitate-induced $\mathrm{ER} \mathrm{Ca}^{2+}$ depletion, $\mathrm{IP}_{3}$ generation, ER stress and cell death. ${ }^{30}$ These findings demonstrate the important role of mitochondrial ROS in the palmitate-induced vicious cycle of calcium dysregulation and apoptosis.

\section{FUNCTIONAL CONSEQUENCES OF LIPOTOXICITY AND IMPLICATIONS}

Pancreatic beta cell failure and diabetes

During the glucose stimulation of pancreatic $\beta$-cells, insulin synthesis represents more than half of total protein synthesis in this highly specialized cell type. This high synthesis rate of insulin is further exaggerated in the context of insulin resistance, when proinsulin production is approximately 1000000 molecules per minute. ${ }^{123}$ Therefore, ER function in $\beta$-cells is prone to be overloaded in individuals on a highcalorie diet with limited physical activity. Saturated FFAs exert extra stress on $\beta$-cells due to the induction of ROS production. In an attempt to overcome this stress, $\beta$-cells upregulate the expression of chaperone proteins and reduce the ER workload as part of the ER stress response. Once a threshold of ER stress has been reached, palmitate may shift the $\beta$-cell response from physiologic adaptation to a pro-apoptotic program. ${ }^{124}$

ER stress in $\beta$-cells is a critical step in the pathogenesis of type 2 diabetes (Figure 3). Both high glucose and lipid stimulation produce mitochondrial ROS synergistically. Compared to other cell types, $\beta$-cells are highly susceptible to oxidative stress. High glucose and/or palmitate have been reported to decrease SERCA2b expression and ER $\mathrm{Ca}^{2+}$ level in $\beta$-cells. ${ }^{92}$ Inflammatory cytokines, acting as pathogenic molecules in type 1 diabetes, also attenuate SERCA2b expression in $\beta$-cells. ${ }^{125}$ Therefore, ER stress caused by insufficient ER $\mathrm{Ca}^{2+}$ content may be an important factor in the development of diabetes. In addition, the deletion or inactivation of WFS1, 


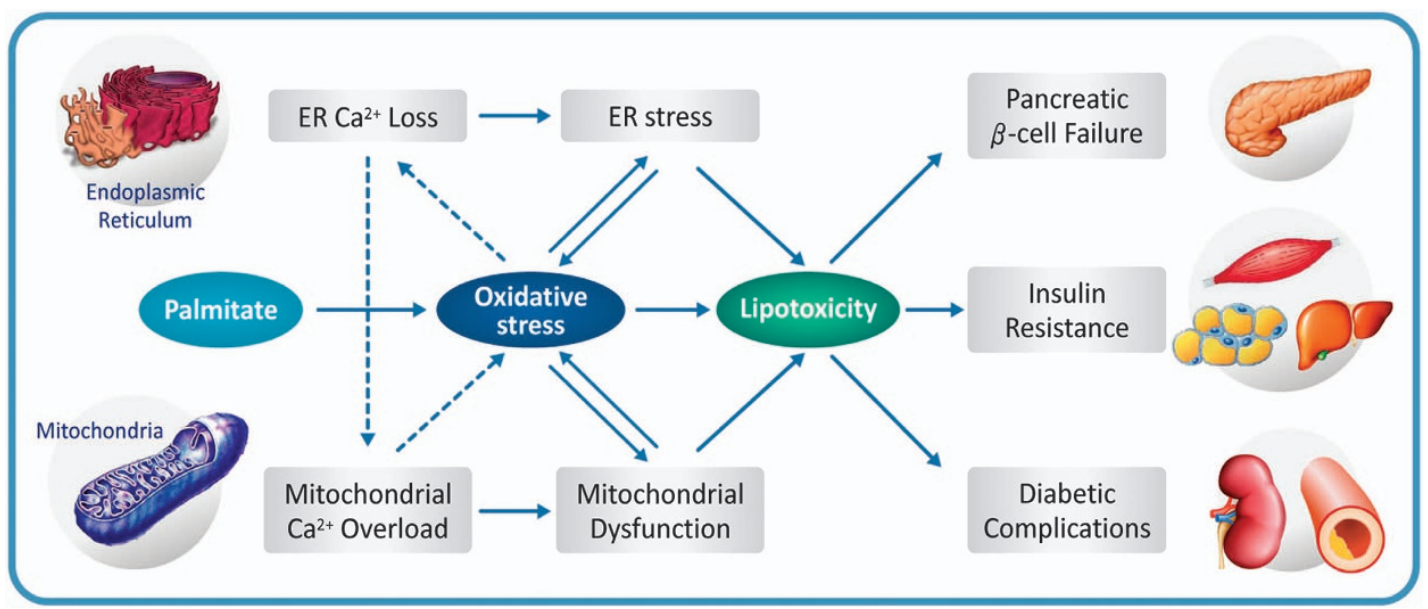

Figure 3 Proposed mechanism of lipotoxicity in type 2 diabetes. Oxidative stress and calcium dysregulation form a vicious cycle that disturbs critical organelle function. Lipotoxicity resulting from ER stress and mitochondrial dysfunction contributes to pancreatic $\beta$-cell failure, insulin resistance in target tissues and diabetic complications.

which is mutated in Wolfram syndrome, results in reduced ER $\mathrm{Ca}^{2+}$ content and increases ER stress in $\beta$-cells. ${ }^{92,126}$ Genome studies revealed a link between WFS1 polymorphism and a high risk of type 2 diabetes, ${ }^{127}$ which may be due to the reported ER stress in $\beta$-cells. Palmitate, but not oleate, has been shown to trigger NF- $\mathrm{kB}$ activation and ER stress, which may be one mechanism to induce interleukin $1 \beta$ (IL-1 $\beta$ ) and downstream chemokines and cytokines, culminating in mild inflammation in human islets, although this does not directly cause $\beta$-cell dysfunction and apoptosis. ${ }^{128}$

Mitochondrial function in $\beta$-cells is particularly important because glucose/lipid/amino acid metabolism and insulin secretion depend on mitochondrial function. ${ }^{129}$ It has been demonstrated that mitochondrial morphodynamics protect $\beta$-cells from lipotoxicity. ${ }^{130}$ The inhibition of mitochondrial fission and/or defective mitophagy augments sensitivity to glucolipotoxicity. ${ }^{122}$ Mitochondrial $\mathrm{Ca}^{2+}$ is a crucial regulator of mitochondrial energy metabolism, ${ }^{108}$ as mentioned earlier. Therefore, $\mathrm{Ca}^{2+}$ transport from the ER to the mitochondria can affect mitochondrial metabolism as well as $\beta$-cell death. The pathogenic role of the ER-mitochondrial $\mathrm{Ca}^{2+}$ connection in mitochondrial dysfunction and $\beta$-cell failure by palmitate deserves further investigation.

\section{Insulin resistance in target tissues}

It is well-known that palmitate induces insulin resistance by disrupting intracellular insulin signaling in diverse cell types such as hepatocytes, cardiac and skeletal muscle cells, adipocytes, podocytes, hypothalamic neurons, and pancreatic $\alpha$-cells. ${ }^{42,131-136}$ Palmitate exposure activates JNK, which phosphorylates IRS-1 on serine $e^{307}$ and decreases Akt phosphorylation, leading to the impairment of downstream signaling. Intriguingly, neuronal cells are more prone to the cytotoxic effects of palmitate. Compared to other cell types, neuronal cells are sensitive to lower doses and shorter exposure time. ${ }^{135}$ Oleate, again, prevents palmitate-induced insulin resistance in many cases. ${ }^{137-139}$
Palmitate-induced oxidative stress is the main mechanism disrupting insulin signaling (Figure 3). As discussed above, ROS are derived from multiple sources: mitochondrial ETC, DAG-PKC-NOX and CHOP-ERO1 $\alpha$. ROS can activate not only JNK but also other serine kinases, such as p38 MAPK, GSK-3 $\beta$ and IKK $\beta$ in skeletal muscle. ${ }^{140}$ In HepG2 cells treated with palmitate, p38 MAPK and JNK activities are significantly attenuated by siRNA-mediated NOX3 silencing. ${ }^{42}$ However, in another hepatic cell line, ROS-induced JNK activation was not completely reversed, even when efficiently suppressing ROS levels using antioxidants. ${ }^{45}$ The findings suggest that other mechanisms are also involved in palmitate-induced insulin resistance. One possible explanation is the intracellular accumulation of ceramide, which may activate JNK via mixed lineage kinase- $3 .^{141,142}$

$\mathrm{Ca}^{2+}$ is another modulator of insulin signaling, the molecular mechanisms of which are still poorly understood. ${ }^{143}$ $\mathrm{Ca}^{2+} /$ calmodulin was suggested to have an important role in the insulin-mediated translocation and exocytosis of glucose transporter type 4 (GLUT4) vesicles in 3T3-L1 adipocytes. A more recent study found that the $\mathrm{Ca}^{2+}$ chelator BAPTA ${ }^{144}$ operates through the depolarization of microtubules rather than $\mathrm{Ca}^{2+}$ chelation. ${ }^{145}$ In L6 myotubes, ER $\mathrm{Ca}^{2+}$ release through both ryanodine receptor 1 (RYR1) and $\mathrm{IP}_{3} \mathrm{R}$ promotes insulin-dependent GLUT4 trafficking to the plasma membrane. ${ }^{146}$ Palmitate impairs mitochondrial calcium retention capacity and impairs insulin-stimulated GLUT4 translocation in L6 myotubes, which was fully restored by adding an inhibitor of PT pore opening. ${ }^{147}$ Finally, several studies have suggested that either enlarged or insufficient MAMs fail to maintain normal ER-mitochondrial $\mathrm{Ca}^{2+}$ homeostasis. Altered MAM structures may, therefore, indirectly affect the translocation and fusion of GLUT4 vesicles with the plasma membrane. ${ }^{148}$ Does palmitate-induced ER-mitochondrial $\mathrm{Ca}^{2+}$ dysregulation affect GLUT4 trafficking in a ROS-independent manner? Does palmitate affect insulindependent and/or contraction-dependent GLUT4 translocation 
in muscle? More studies are needed to address such potential $\mathrm{Ca}^{2+}$-mediated mechanisms of lipotoxicity.

\section{Diabetic complications}

Chronic diabetic complications have traditionally been attributed to long-term exposure to high glucose. The four classical pathways of hyperglycemia-induced complications include (1) increased polyol pathway flux, (2) increased intracellular formation of advanced glycation end products (AGE), (3) the activation of PKC and (4) the stimulation of the hexosamine pathway. Those pathways are connected by the fact that intracellular high glucose induces elevated mitochondrial ROS production, which leads to a decrease in GAPDH activity. As a result, upstream glycolytic metabolites are diverted into the pathogenic pathways described above. ${ }^{149}$ In addition, high glucose augments the expression and activity of members of the NOX family. ${ }^{150-152}$ A detailed description of this crosstalk between NOX and mitochondrial ROS generation has been described elsewhere. ${ }^{55,153}$

Intriguingly, accumulating evidence supports a synergistic effect between palmitate and high glucose leading to diabetic complications. Such findings have led to the concept of glucolipotoxicity. Oxidative stress may be a common mechanism explaining the harmful synergistic effects of the two nutrients. In bovine and human retinal endothelial cells, NOX2-derived ROS overproduction was significantly higher when the cells were exposed to palmitate and high glucose rather than high glucose alone. Consequently, mitochondrial DNA damage is observed as early as $48 \mathrm{~h}$ when bovine retinal cells are exposed to palmitate and high glucose. Similar mtDNA damage was only observed after $96 \mathrm{~h}$ when high glucose was added alone. ${ }^{154}$ The separate exposure of HUVEC cells to either palmitate or high glucose increases ROS production, but the highest ROS levels were observed upon treatment with both. ${ }^{155}$ These experiments clearly demonstrate that glucolipotoxicity, which was originally proposed to affect $\beta$-cells, may be similarly harmful to other tissues.

In diabetic nephropathy, functional and structural alterations in podocytes accompany disease progression. In this cell type, palmitate reduces tyrosine phosphorylation following insulin stimulation. ${ }^{156}$ This defect downstream of insulin receptor signaling also impairs GLUT4 translocation in podocytes. Palmitate-induced intracellular calcium dysregulation also participates in diabetic nephropathy. In podocytes, elevated cytosolic $\mathrm{Ca}^{2+}$ concentrations induce actin remodeling, which increases albumin permeability. These structural alterations in podocytes also have a critical role in the pathogenesis of proteinuric glomerular disease..$^{30}$

Furthermore, elevated palmitate may also exert harmful effects in periodontitis linked to type 2 diabetes. In mice fed a high-fat diet, which serve as a model of type 2 diabetes, CD36 is overexpressed in gingival fibroblasts. In human gingival fibroblasts, palmitate also provokes mRNA expression of proinflammatory cytokines and chemokines, as well as IL-6, IL-8 and CXCL1. ${ }^{157}$ This evidence supports the hypothesis that palmitate exposure may worsen diabetic complications.

\section{CONCLUSION}

The accumulation of palmitate and derived metabolites, e.g., DAG, induces oxidative stress and $\mathrm{ER} \mathrm{Ca}^{2+}$ depletion, leading to ER stress and mitochondrial dysfunction. Excessive ER $\mathrm{Ca}^{2+}$ release and mitochondrial $\mathrm{Ca}^{2+}$ overload further amplify oxidative stress. This close interaction between oxidative stress and $\mathrm{Ca}^{2+}$ dysregulation results in a vicious cycle of increasingly impaired cell function and death. The activation of stores-operated $\mathrm{Ca}^{2+}$ entry may chronically disturb cytosolic and organellar $\mathrm{Ca}^{2+}$ homeostasis; this hypothesis will require further investigation. The disruption of $\mathrm{Ca}^{2+}$ regulation by oxidative stress also contributes to insulin resistance. These hypotheses provide an integrated mechanistic view of lipotoxicity, which has pivotal roles during the progress of diabetes and its complications. In this review, we have suggested future therapeutic approaches to type 2 diabetes via interference with the basic molecular mechanisms overstimulated during lipotoxicity.

\section{CONFLICT OF INTEREST}

The authors declare no conflict of interest.

\section{ACKNOWLEDGEMENTS}

This research was supported by a grant (HI16C1501) from the Korea Health Technology R\&D Project through the Korea Health Industry Development Institute (KHIDI), funded by the Ministry of Health and Welfare, Republic of Korea (awarded to IKL).

1 Choi CS, Savage DB, Kulkarni A, Yu XX, Liu ZX, Morino K et al. Suppression of diacylglycerol acyltransferase-2 (DGAT2), but not DGAT1, with antisense oligonucleotides reverses diet-induced hepatic steatosis and insulin resistance. J Biol Chem 2007; 282: 22678-22688.

2 Hagenfeldt L, Wahren J, Pernow B, Raf L. Uptake of individual free fatty acids by skeletal muscle and liver in man. J Clin Invest 1972; 51: 2324-2330.

3 Fraze E, Donner CC, Swislocki AL, Chiou YA, Chen YD, Reaven GM. Ambient plasma free fatty acid concentrations in noninsulin-dependent diabetes mellitus: evidence for insulin resistance. J Clin Endocrinol Metab 1985; 61: 807-811.

4 Miles JM, Wooldridge D, Grellner WJ, Windsor S, Isley WL, Klein S et al. Nocturnal and postprandial free fatty acid kinetics in normal and type 2 diabetic subjects: effects of insulin sensitization therapy. Diabetes 2003; 52: 675-681.

5 Charles MA, Eschwege E, Thibult N, Claude JR, Warnet JM, Rosselin GE et al. The role of non-esterified fatty acids in the deterioration of glucose tolerance in Caucasian subjects: results of the Paris Prospective Study. Diabetologia 1997; 40: 1101-1106.

6 Abumrad NA, el-Maghrabi MR, Amri EZ, Lopez E, Grimaldi PA. Cloning of a rat adipocyte membrane protein implicated in binding or transport of long-chain fatty acids that is induced during preadipocyte differentiation. Homology with human CD36. J Biol Chem 1993; 268: 17665-17668.

7 Van Nieuwenhoven FA, Verstijnen CP, Abumrad NA, Willemsen PH, Van Eys GJ, Van der Vusse GJ et al. Putative membrane fatty acid translocase and cytoplasmic fatty acid-binding protein are co-expressed in rat heart and skeletal muscles. Biochem Biophys Res Commun 1995; 207: 747-752.

8 Coburn CT, Knapp FF Jr, Febbraio M, Beets AL, Silverstein RL, Abumrad NA. Defective uptake and utilization of long chain fatty acids in muscle and adipose tissues of CD36 knockout mice. J Biol Chem 2000; 275: 32523-32529.

9 He J, Lee JH, Febbraio M, Xie W. The emerging roles of fatty acid translocase/CD36 and the aryl hydrocarbon receptor in fatty liver disease. Exp Biol Med (Maywood) 2011; 236: 1116-1121. 
10 Swerlick RA, Lee KH, Wick TM, Lawley TJ. Human dermal microvascular endothelial but not human umbilical vein endothelial cells express CD36 in vivo and in vitro. J Immunol 1992; 148: 78-83.

11 Endemann G, Stanton LW, Madden KS, Bryant CM, White RT, Protter AA CD36 is a receptor for oxidized low density lipoprotein. J Biol Chem. 1993; 268: 11811-11816.

12 Huh HY, Pearce SF, Yesner LM, Schindler JL, Silverstein RL. Regulated expression of CD36 during monocyte-to-macrophage differentiation: potential role of CD36 in foam cell formation. Blood 1996; 87: 2020-2028.

13 Noushmehr H, D'Amico E, Farilla L, Hui H, Wawrowsky KA, Mlynarski W et al. Fatty acid translocase (FAT/CD36) is localized on insulin-containing granules in human pancreatic beta-cells and mediates fatty acid effects on insulin secretion. Diabetes 2005; 54: 472-481.

14 Mayrhofer C, Krieger S, Huttary N, Chang MW, Grillari J, Allmaier G et al. Alterations in fatty acid utilization and an impaired antioxidant defense mechanism are early events in podocyte injury: a proteomic analysis. Am J Pathol 2009; 174: 1191-1202.

15 Ibrahimi A, Bonen A, Blinn WD, Hajri T, Li X, Zhong $\mathrm{K}$ et al. Muscle-specific overexpression of FAT/CD36 enhances fatty acid oxidation by contracting muscle, reduces plasma triglycerides and fatty acids, and increases plasma glucose and insulin. J Biol Chem 1999; 274: 26761-26766.

16 Febbraio M, Abumrad NA, Hajjar DP, Sharma K, Cheng W, Pearce SF et al. A null mutation in murine CD36 reveals an important role in fatty acid and lipoprotein metabolism. J Biol Chem 1999; 274: 19055-19062.

17 Garbacz WG, Lu P, Miller TM, Poloyac SM, Eyre NS, Mayrhofer G et al. Hepatic overexpression of CD36 improves glycogen homeostasis and attenuates high-fat diet induced hepatic steatosis and insulin resistance. Mol Cell Biol 2016; 36: 2715-2727.

18 Hames KC, Vella A, Kemp BJ, Jensen MD. Free fatty acid uptake in humans with CD36 deficiency. Diabetes 2014; 63: 3606-3614.

19 Wilson CG, Tran JL, Erion DM, Vera NB, Febbraio M, Weiss EJ. Hepatocyte-Specific Disruption of CD36 Attenuates Fatty Liver and Improves Insulin Sensitivity in HFD-Fed Mice. Endocrinology 2016; 157: 570-585.

20 Silverstein RL, Li W, Park YM, Rahaman SO. Mechanisms of cell signaling by the scavenger receptor CD36: implications in atherosclerosis and thrombosis. Trans Am Clin Climatol Assoc 2010; 121: 206-220.

21 Kuda O, Jenkins CM, Skinner JR, Moon SH, Su X, Gross RW et al. CD36 protein is involved in store-operated calcium flux, phospholipase A2 activation, and production of prostaglandin E2. J Biol Chem 2011; 286 17785-17795.

22 Abdoul-Azize S, Selvakumar S, Sadou H, Besnard P, Khan NA. Ca2+ signaling in taste bud cells and spontaneous preference for fat: unresolved roles of CD36 and GPR120. Biochimie 2014; 96: 8-13.

23 Kim YW, Moon JS, Seo YJ, Park SY, Kim JY, Yoon JS et al. Inhibition of fatty acid translocase cluster determinant 36 (CD36), stimulated by hyperglycemia, prevents glucotoxicity in INS-1 cells. Biochem Biophys Res Commun 2012; 420: 462-466.

24 Hua W, Huang HZ, Tan LT, Wan JM, Gui HB, Zhao L et al. CD36 mediated fatty acid-induced podocyte apoptosis via oxidative stress. PLOS ONE 2015; 10: e0127507.

25 Wallin $\mathrm{T}$, Ma Z, Ogata $\mathrm{H}$, Jorgensen $\mathrm{IH}$, lezzi M, Wang $\mathrm{H}$ et al. Facilitation of fatty acid uptake by CD36 in insulin-producing cells reduces fatty-acidinduced insulin secretion and glucose regulation of fatty acid oxidation. Biochim Biophys Acta 2010; 1801: 191-197.

26 Gharib M, Tao H, Fungwe TV, Hajri T. Cluster differentiating 36 (CD36) deficiency attenuates obesity-associated oxidative stress in the heart. PLOS ONE 2016; 11: e0155611.

27 Febbraio M, Podrez EA, Smith JD, Hajjar DP, Hazen SL, Hoff HF et al. Targeted disruption of the class $\mathrm{B}$ scavenger receptor CD36 protects against atherosclerotic lesion development in mice. J Clin Invest 2000; 105: 1049-1056.

28 Harmon CM, Luce P, Beth AH, Abumrad NA. Labeling of adipocyte membranes by sulfo- $\mathrm{N}$-succinimidyl derivatives of long-chain fatty acids: inhibition of fatty acid transport. J Membr Biol 1991; 121: 261-268.

29 Coort SL, Willems J, Coumans WA, van der Vusse GJ, Bonen A, Glatz JF et al. Sulfo-N-succinimidyl esters of long chain fatty acids specifically inhibit fatty acid translocase (FAT/CD36)-mediated cellular fatty acid uptake. Mol Cell Biochem 2002; 239: 213-219.

30 Xu S, Nam SM, Kim JH, Das R, Choi SK, Nguyen TT et al. Palmitate induces ER calcium depletion and apoptosis in mouse podocytes subsequent to mitochondrial oxidative stress. Cell Death Dis 2015; 6: e1976.

31 Souza AC, Bocharov AV, Baranova IN, Vishnyakova TG, Huang YG, Wilkins KJ et al. Antagonism of scavenger receptor CD36 by 5A peptide prevents chronic kidney disease progression in mice independent of blood pressure regulation. Kidney Int 2016; 89: 809-822.

32 Trachootham D, Lu W, Ogasawara MA, Nilsa RD, Huang P. Redox regulation of cell survival. Antioxid Redox Signal 2008; 10: 1343-1374.

33 Wehinger S, Ortiz R, Diaz MI, Aguirre A, Valenzuela M, Llanos P et al. Phosphorylation of caveolin-1 on tyrosine-14 induced by ROS enhances palmitate-induced death of beta-pancreatic cells. Biochim Biophys Acta 2015; 1852: 693-708.

34 Liu J, Chang F, Li F, Fu H, Wang J, Zhang S et al. Palmitate promotes autophagy and apoptosis through ROS-dependent JNK and p38 MAPK. Biochem Biophys Res Commun 2015; 463: 262-267.

35 Carlsson C, Borg LA, Welsh N. Sodium palmitate induces partial mitochondrial uncoupling and reactive oxygen species in rat pancreatic islets in vitro. Endocrinology 1999; 140: 3422-3428.

36 Sato Y, Fujimoto S, Mukai E, Sato H, Tahara Y, Ogura K et al. Palmitate induces reactive oxygen species production and beta-cell dysfunction by activating nicotinamide adenine dinucleotide phosphate oxidase through Src signaling. J Diabetes Investig 2014; 5: 19-26.

37 Barlow J, Affourtit C. Novel insights into pancreatic beta-cell glucolipotoxicity from real-time functional analysis of mitochondrial energy metabolism in INS-1E insulinoma cells. Biochem J 2013; 456: 417-426.

38 Joseph LC, Barca E, Subramanyam P, Komrowski M, Pajvani U, Colecraft $\mathrm{HM}$ et al. Inhibition of NAPDH oxidase 2 (NOX2) Prevents oxidative stress and mitochondrial abnormalities caused by saturated fat in cardiomyocytes. PLoS ONE 2016; 11: e0145750.

39 Brodeur MR, Bouvet C, Barrette M, Moreau P. Palmitic acid increases medial calcification by inducing oxidative stress. J Vasc Res 2013; 50: 430-441.

40 Yamagishi S, Okamoto T, Amano S, Inagaki Y, Koga K, Koga M et al. Palmitate-induced apoptosis of microvascular endothelial cells and pericytes. Mol Med 2002; 8: 179-184.

41 Taheripak G, Bakhtiyari S, Rajabibazl M, Pasalar P, Meshkani R. Protein tyrosine phosphatase $1 \mathrm{~B}$ inhibition ameliorates palmitate-induced mitochondrial dysfunction and apoptosis in skeletal muscle cells. Free Radic Biol Med 2013; 65: 1435-1446.

42 Gao D, Nong S, Huang X, Lu Y, Zhao H, Lin Y et al. The effects of palmitate on hepatic insulin resistance are mediated by NADPH Oxidase 3-derived reactive oxygen species through JNK and p38MAPK pathways. J Biol Chem 2010; 285: 29965-29973.

43 Davis JE, Gabler NK, Walker-Daniels J, Spurlock ME. The c-Jun $\mathrm{N}$-terminal kinase mediates the induction of oxidative stress and insulin resistance by palmitate and toll-like receptor 2 and 4 ligands in 3T3-L1 adipocytes. Horm Metab Res 2009; 41: 523-530.

44 Lambertucci RH, Hirabara SM, Silveira Ldos R, Levada-Pires AC, Curi R, Pithon-Curi TC. Palmitate increases superoxide production through mitochondrial electron transport chain and $\mathrm{NADPH}$ oxidase activity in skeletal muscle cells. J Cell Physiol 2008; 216: 796-804.

45 Nakamura S, Takamura T, Matsuzawa-Nagata N, Takayama H, Misu H, Noda $\mathrm{H}$ et al. Palmitate induces insulin resistance in $\mathrm{H} 4 \mathrm{IIEC3}$ hepatocytes through reactive oxygen species produced by mitochondria. J Biol Chem 2009; 284: 14809-14818.

46 Boudina S, Sena S, Theobald H, Sheng X, Wright JJ, Hu XX et al. Mitochondrial energetics in the heart in obesity-related diabetes: direct evidence for increased uncoupled respiration and activation of uncoupling proteins. Diabetes 2007; 56: 2457-2466.

47 Choi SE, Jung IR, Lee YJ, Lee SJ, Lee JH, Kim Y et al. Stimulation of lipogenesis as well as fatty acid oxidation protects against palmitateinduced INS-1 beta-cell death. Endocrinology 2011; 152: 816-827.

48 Namgaladze D, Lips S, Leiker TJ, Murphy RC, Ekroos K, Ferreiros N et al. Inhibition of macrophage fatty acid beta-oxidation exacerbates palmitateinduced inflammatory and endoplasmic reticulum stress responses. Diabetologia 2014; 57: 1067-1077.

49 Fu D, Lu J, Yang S. Oleic/palmitate induces apoptosis in human articular chondrocytes via upregulation of NOX4 expression and ROS production. Ann Clin Lab Sci 2016; 46: 353-359.

50 Das R, Xu S, Quan X, Nguyen TT, Kong ID, Chung CH et al. Upregulation of mitochondrial Nox4 mediates TGF-beta-induced apoptosis in cultured mouse podocytes. Am J Physiol Renal Physiol 2014; 306: F155-F167. 
51 Ago T, Kuroda J, Pain J, Fu C, Li H, Sadoshima J. Upregulation of Nox4 by hypertrophic stimuli promotes apoptosis and mitochondrial dysfunction in cardiac myocytes. Circ Res 2010; 106: 1253-1264.

52 Watson ML, Macrae K, Marley AE, Hundal HS. Chronic effects of palmitate overload on nutrient-induced insulin secretion and autocrine signalling in pancreatic MIN6 beta cells. PLoS ONE 2011; 6: e25975.

53 Macrae K, Stretton C, Lipina C, Blachnio-Zabielska A, Baranowski M, Gorski J et al. Defining the role of DAG, mitochondrial function, and lipid deposition in palmitate-induced proinflammatory signaling and its counter-modulation by palmitoleate. J Lipid Res 2013; 54: 2366-2378.

54 Leamy AK, Egnatchik RA, Shiota M, Ivanova PT, Myers DS, Brown HA et al. Enhanced synthesis of saturated phospholipids is associated with ER stress and lipotoxicity in palmitate treated hepatic cells. J Lipid Res 2014; 55: 1478-1488.

55 Dikalov S. Cross talk between mitochondria and NADPH oxidases. Free Radic Biol Med 2011; 51: 1289-1301.

56 Lu G, Greene EL, Nagai T, Egan BM. Reactive oxygen species are critical in the oleic acid-mediated mitogenic signaling pathway in vascular smooth muscle cells. Hypertension 1998; 32: 1003-1010.

57 Koulajian K, Desai T, Liu GC, Ivovic A, Patterson JN, Tang C et al. NADPH oxidase inhibition prevents beta cell dysfunction induced by prolonged elevation of oleate in rodents. Diabetologia 2013; 56: 1078-1087.

58 Pang J, Cui J, Gong H, Xi C, Zhang TM. Effect of NAD on PARP-mediated insulin sensitivity in oleic acid treated hepatocytes. J Cell Physiol 2015; 230: 1607-1613.

59 Lamers D, Schlich R, Horrighs A, Cramer A, Sell H, Eckel J. Differential impact of oleate, palmitate, and adipokines on expression of NF-kappaB target genes in human vascular smooth muscle cells. Mol Cell Endocrinol 2012; 362: 194-201.

60 Park EJ, Lee AY, Chang SH, Yu KN, Kim JH, Cho MH. Role of p53 in the cellular response following oleic acid accumulation in Chang liver cells. Toxicol Lett 2014; 224: 114-120.

61 Yuzefovych L, Wilson G, Rachek L. Different effects of oleate vs. palmitate on mitochondrial function, apoptosis, and insulin signaling in L6 skeletal muscle cells: role of oxidative stress. Am J Physiol Endocrinol Metab 2010; 299: E1096-E1105.

62 Ellgaard L, Molinari M, Helenius A. Setting the standards: quality control in the secretory pathway. Science 1999; 286: 1882-1888.

63 Tu BP, Weissman JS. Oxidative protein folding in eukaryotes: mechanisms and consequences. J Cell Biol 2004; 164: 341-346.

64 Malhotra JD, Kaufman RJ. Endoplasmic reticulum stress and oxidative stress: a vicious cycle or a double-edged sword? Antioxid Redox Signal 2007: 9: 2277-2293.

65 Cao SS, Kaufman RJ. Endoplasmic reticulum stress and oxidative stress in cell fate decision and human disease. Antioxid Redox Signal 2014; 21: 396-413.

66 Schroder M, Kaufman RJ. The mammalian unfolded protein response. Annu Rev Biochem 2005; 74: 739-789.

67 Back SH, Kaufman RJ. Endoplasmic reticulum stress and type 2 diabetes. Annu Rev Biochem 2012; 81: 767-793.

68 Cnop M, Ladriere L, Igoillo-Esteve M, Moura RF, Cunha DA. Causes and cures for endoplasmic reticulum stress in lipotoxic beta-cell dysfunction. Diabetes Obes Metab 2010; 12(Suppl 2): 76-82.

69 Hage Hassan R, Bourron O, Hajduch E. Defect of insulin signal in peripheral tissues: Important role of ceramide. World J Diabetes 2014; 5: 244-257.

70 Chaurasia B, Summers SA. Ceramides-lipotoxic inducers of metabolic disorders. Trends Endocrinol Metab 2015; 26: 538-550.

71 Ueda N. Ceramide-induced apoptosis in renal tubular cells: a role of mitochondria and sphingosine-1-phoshate. Int J Mol Sci 2015; 16: 5076-5124.

72 Raichur S, Wang ST, Chan PW, Li Y, Ching J, Chaurasia B et al. CerS2 haploinsufficiency inhibits beta-oxidation and confers susceptibility to diet-induced steatohepatitis and insulin resistance. Cell Metab 2014; 20 : 687-695.

73 Liu Z, Xia Y, Li B, Xu H, Wang C, Liu Y et al. Induction of ER stress-mediated apoptosis by ceramide via disruption of $\mathrm{ER} \mathrm{Ca}(2+)$ homeostasis in human adenoid cystic carcinoma cells. Cell Biosci 2014; 4: 71.

74 Soumura M, Kume S, Isshiki K, Takeda N, Araki S, Tanaka Y et al. Oleate and eicosapentaenoic acid attenuate palmitate-induced inflammation and apoptosis in renal proximal tubular cell. Biochem Biophys Res Commun 2010: 402: 265-271.
75 Sieber J, Lindenmeyer MT, Kampe K, Campbell KN, Cohen CD, Hopfer H et al. Regulation of podocyte survival and endoplasmic reticulum stress by fatty acids. Am J Physiol Renal Physiol 2010; 299: F821-F829.

76 Listenberger LL, Han X, Lewis SE, Cases S, Farese RV Jr, Ory DS et al. Triglyceride accumulation protects against fatty acid-induced lipotoxicity. Proc Natl Acad Sci USA 2003; 100: 3077-3082.

77 Thorn K, Bergsten P. Fatty acid-induced oxidation and triglyceride formation is higher in insulin-producing MIN6 cells exposed to oleate compared to palmitate. J Cell Biochem 2010; 111: 497-507.

78 Henique C, Mansouri A, Fumey G, Lenoir V, Girard J, Bouillaud F et al. Increased mitochondrial fatty acid oxidation is sufficient to protect skeletal muscle cells from palmitate-induced apoptosis. J Biol Chem 2010; 285: 36818-36827.

79 Sieber J, Weins A, Kampe K, Gruber S, Lindenmeyer MT, Cohen CD et al. Susceptibility of podocytes to palmitic acid is regulated by stearoyl-CoA desaturases 1 and 2. Am J Pathol 2013; 183: 735-744.

80 Heard A, Thompson J, Carver J, Bakey M, Wang XR. Targeting molecular chaperones for the treatment of cystic fibrosis: is it a viable approach? Curr Drug Targets 2015; 16: 958-964.

81 Silverman GA, Pak SC, Perlmutter DH. Disorders of protein misfolding: alpha-1-antitrypsin deficiency as prototype. J Pediatr 2013; 163: 320-326.

82 Mukherjee A, Morales-Scheihing D, Butler PC, Soto C. Type 2 diabetes as a protein misfolding disease. Trends Mol Med 2015; 21: 439-449.

83 Moreno JA, Radford H, Peretti D, Steinert JR, Verity N, Martin MG et al. Sustained translational repression by elF2alpha-P mediates prion neurodegeneration. Nature 2012; 485: 507-511.

84 Pfaffenbach KT, Gentile CL, Nivala AM, Wang D, Wei Y, Pagliassotti MJ. Linking endoplasmic reticulum stress to cell death in hepatocytes: roles of C/EBP homologous protein and chemical chaperones in palmitatemediated cell death. Am J Physiol Endocrinol Metab 2010; 298: E1027-E1035.

85 Boyce M, Bryant KF, Jousse C, Long K, Harding HP, Scheuner D et al. A selective inhibitor of elF2alpha dephosphorylation protects cells from ER stress. Science 2005; 307: 935-939.

86 Cnop M, Ladriere L, Hekerman P, Ortis F, Cardozo AK, Dogusan Z et al. Selective inhibition of eukaryotic translation initiation factor 2 alpha dephosphorylation potentiates fatty acid-induced endoplasmic reticulum stress and causes pancreatic beta-cell dysfunction and apoptosis. J Biol Chem 2007; 282: 3989-3997.

87 Ladriere L, Igoillo-Esteve M, Cunha DA, Brion JP, Bugliani M, Marchetti P et al. Enhanced signaling downstream of ribonucleic Acid-activated protein kinase-like endoplasmic reticulum kinase potentiates lipotoxic endoplasmic reticulum stress in human islets. J Clin Endocrinol Metab 2010; 95: 1442-1449.

88 Cunha DA, Hekerman P, Ladriere L, Bazarra-Castro A, Ortis F, Wakeham MC et al. Initiation and execution of lipotoxic ER stress in pancreatic beta-cells. J Cell Sci. 2008; 121(Pt 14): 2308-2318.

89 Malhi H, Kropp EM, Clavo VF, Kobrossi CR, Han J, Mauer AS et al. C/EBP homologous protein-induced macrophage apoptosis protects mice from steatohepatitis. J Biol Chem 2013; 288: 18624-18642.

90 Mekahli D, Bultynck G, Parys JB, De Smedt H, Missiaen L. Endoplasmicreticulum calcium depletion and disease. Cold Spring Harb Perspect Biol 2011; 3: a004317.

91 Gwiazda KS, Yang TL, Lin Y, Johnson JD. Effects of palmitate on ER and cytosolic Ca2+ homeostasis in beta-cells. Am J Physiol Endocrinol Metab 2009; 296: E690-E701.

92 Hara T, Mahadevan J, Kanekura K, Hara M, Lu S, Urano F. Calcium efflux from the endoplasmic reticulum leads to beta-cell death. Endocrinology 2014; 155: 758-768.

93 Fu S, Yang L, Li P, Hofmann O, Dicker L, Hide W et al. Aberrant lipid metabolism disrupts calcium homeostasis causing liver endoplasmic reticulum stress in obesity. Nature 2011; 473: 528-531.

94 Haynes CM, Titus EA, Cooper AA. Degradation of misfolded proteins prevents ER-derived oxidative stress and cell death. Mol Cell 2004; 15 : 767-776.

95 Li G, Mongillo M, Chin KT, Harding H, Ron D, Marks AR et al. Role of ERO1-alpha-mediated stimulation of inositol 1,4,5-triphosphate receptor activity in endoplasmic reticulum stress-induced apoptosis. J Cell Biol 2009; 186: 783-792.

96 Weissmann N, Sydykov A, Kalwa H, Storch U, Fuchs B, Mederos y Schnitzler M et al. Activation of TRPC6 channels is essential for lung ischaemia-reperfusion induced oedema in mice. Nat Commun 2012; 3. 649 . 
97 Hong JH, Moon SJ, Byun HM, Kim MS, Jo H, Bae YS et al. Critical role of phospholipase Cgamma1 in the generation of $\mathrm{H} 2 \mathrm{O} 2$-evoked [Ca2+]i oscillations in cultured rat cortical astrocytes. J Biol Chem 2006; 281: 13057-13067.

98 Scorrano L, Oakes SA, Opferman JT, Cheng EH, Sorcinelli MD, Pozzan T et al. BAX and BAK regulation of endoplasmic reticulum $\mathrm{Ca} 2+$ : a control point for apoptosis. Science 2003; 300: 135-139.

99 Demaurex N, Distelhorst C. Cell biology. Apoptosis-the calcium connection. Science 2003; 300: 65-67.

100 Csordas G, Renken C, Varnai P, Walter L, Weaver D, Buttle KF et al. Structural and functional features and significance of the physical linkage between ER and mitochondria. J Cell Biol 2006; 174: 915-921.

101 Arruda AP, Pers BM, Parlakgul G, Guney E, Inouye K, Hotamisligil GS. Chronic enrichment of hepatic endoplasmic reticulum-mitochondria contact leads to mitochondrial dysfunction in obesity. Nat Med 2014; 20: $1427-1435$.

102 Tubbs E, Theurey P, Vial G, Bendridi N, Bravard A, Chauvin MA et al. Mitochondria-associated endoplasmic reticulum membrane (MAM) integrity is required for insulin signaling and is implicated in hepatic insulin resistance. Diabetes 2014; 63: 3279-3294.

103 Rizzuto R, De Stefani D, Raffaello A, Mammucari C. Mitochondria as sensors and regulators of calcium signalling. Nat Rev Mol Cell Biol 2012; 13: $566-578$.

104 Arruda AP, Hotamisligil GS. Calcium homeostasis and organelle function in the pathogenesis of obesity and diabetes. Cell Metab 2015; 22: 381-397.

105 Choi SE, Kim HE, Shin HC, Jang HJ, Lee KW, Kim Y et al. Involvement of $\mathrm{Ca} 2+-$ mediated apoptotic signals in palmitate-induced MIN6N8a beta cell death. Mol Cell Endocrinol 2007; 272: 50-62.

106 Park KS, Wiederkehr A, Kirkpatrick C, Mattenberger Y, Martinou JC, Marchetti $\mathrm{P}$ et al. Selective actions of mitochondrial fission/fusion genes on metabolism-secretion coupling in insulin-releasing cells. J Biol Chem 2008; 283: 33347-33356.

107 Wiederkehr A, Wollheim CB. Minireview: implication of mitochondria in insulin secretion and action. Endocrinology 2006; 147: 2643-2649.

108 Wiederkehr A, Wollheim CB. Impact of mitochondrial calcium on the coupling of metabolism to insulin secretion in the pancreatic beta-cell. Cell Calcium 2008; 44: 64-76.

109 Del Arco A, Contreras L, Pardo B, Satrustegui J. Calcium regulation of mitochondrial carriers. Biochim Biophys Acta 2016; 1863: 2413-2421.

110 De Marchi U, Thevenet J, Hermant A, Dioum E, Wiederkehr A. Calcium co-regulates oxidative metabolism and ATP synthase-dependent respiration in pancreatic beta cells. J Biol Chem 2014; 289: 9182-9194.

111 Quan X, Nguyen TT, Choi SK, Xu S, Das R, Cha SK et al. Essential role of mitochondrial $\mathrm{Ca} 2+$ uniporter in the generation of mitochondrial $\mathrm{pH}$ gradient and metabolism-secretion coupling in insulin-releasing cells. J Biol Chem 2015; 290: 4086-4096.

112 Pendin D, Greotti E, Pozzan T. The elusive importance of being a mitochondrial $\mathrm{Ca}(2+)$ uniporter. Cell Calcium 2014; 55: 139-145.

113 Pan X, Liu J, Nguyen T, Liu C, Sun J, Teng Y et al. The physiological role of mitochondrial calcium revealed by mice lacking the mitochondrial calcium uniporter. Nat Cell Biol 2013; 15: 1464-1472.

114 Kwong JQ, Lu X, Correll RN, Schwanekamp JA, Vagnozzi RJ, Sargent MA et al. The mitochondrial calcium uniporter selectively matches metabolic output to acute contractile stress in the heart. Cell Rep 2015; 12: 15-22.

$115 \mathrm{Yi} \mathrm{M}$, Weaver D, Hajnoczky G. Control of mitochondrial motility and distribution by the calcium signal: a homeostatic circuit. J Cell Biol 2004; 167: 661-672.

116 Kroemer G, Reed JC. Mitochondrial control of cell death. Nat Med 2000; 6: 513-519.

117 Turner N, Heilbronn LK. Is mitochondrial dysfunction a cause of insulin resistance? Trends Endocrinol Metab 2008; 19: 324-330.

118 Szendroedi J, Phielix E, Roden M. The role of mitochondria in insulin resistance and type 2 diabetes mellitus. Nat Rev Endocrinol 2012; 8: 92-103.

119 Choi SE, Lee YJ, Hwang GS, Chung JH, Lee SJ, Lee JH et al. Supplement of TCA cycle intermediates protects against high glucose/palmitateinduced INS-1 beta cell death. Arch Biochem Biophys 2011; 505: 231-241.

120 Archer SL. Mitochondrial dynamics-mitochondrial fission and fusion in human diseases. N Engl J Med 2013; 369: 2236-2251.

121 Twig G, Elorza A, Molina AJ, Mohamed H, Wikstrom JD, Walzer G et al. Fission and selective fusion govern mitochondrial segregation and elimination by autophagy. EMBO J 2008; 27: 433-446.
122 Molina AJ, Wikstrom JD, Stiles L, Las G, Mohamed H, Elorza A et al. Mitochondrial networking protects beta-cells from nutrient-induced apoptosis. Diabetes 2009; 58: 2303-2315.

123 Schuit FC, In't Veld PA, Pipeleers DG. Glucose stimulates proinsulin biosynthesis by a dose-dependent recruitment of pancreatic beta cells. Proc Natl Acad Sci USA 1988; 85: 3865-3869.

124 Ron D, Walter P. Signal integration in the endoplasmic reticulum unfolded protein response. Nat Rev Mol Cell Biol 2007; 8: 519-529.

125 Cardozo AK, Ortis F, Storling J, Feng YM, Rasschaert J, Tonnesen M et al. Cytokines downregulate the sarcoendoplasmic reticulum pump $\mathrm{Ca} 2+$ ATPase $2 \mathrm{~b}$ and deplete endoplasmic reticulum $\mathrm{Ca} 2+$, leading to induction of endoplasmic reticulum stress in pancreatic beta-cells. Diabetes 2005; 54: 452-461.

126 Fonseca SG, Fukuma M, Lipson KL, Nguyen LX, Allen JR, Oka Y et al. WFS1 is a novel component of the unfolded protein response and maintains homeostasis of the endoplasmic reticulum in pancreatic beta-cells. J Biol Chem 2005; 280: 39609-39615.

127 Sandhu MS, Weedon MN, Fawcett KA, Wasson J, Debenham SL, Daly A et al. Common variants in WFS1 confer risk of type 2 diabetes. Nat Genet 2007; 39: 951-953.

128 Igoillo-Esteve M, Marselli L, Cunha DA, Ladriere L, Ortis F, Grieco FA et al. Palmitate induces a pro-inflammatory response in human pancreatic islets that mimics CCL2 expression by beta cells in type 2 diabetes. Diabetologia 2010; 53: 1395-1405.

129 Wiederkehr A, Wollheim CB. Mitochondrial signals drive insulin secretion in the pancreatic beta-cell. Mol Cell Endocrinol 2012; 353: 128-137.

130 Wiederkehr A, Wollheim CB. Linking fatty acid stress to beta-cell mitochondrial dynamics. Diabetes 2009; 58: 2185-2186.

131 Nobuhara M, Saotome M, Watanabe T, Urushida T, Katoh H, Satoh H et al. Mitochondrial dysfunction caused by saturated fatty acid loading induces myocardial insulin-resistance in differentiated H9c2 myocytes: a novel ex vivo myocardial insulin-resistance model. Exp Cell Res 2013; 319: 955-966.

132 Souto Padron de Figueiredo A, Salmon AB, Bruno F, Jimenez F, Martinez HG, Halade GV et al. Nox2 mediates skeletal muscle insulin resistance induced by a high fat diet. J Biol Chem 2015; 290: 13427-13439.

133 Yang L, Qian Z, Ji H, Yang R, Wang Y, Xi L et al. Inhibitory effect on protein kinase Ctheta by Crocetin attenuates palmitate-induced insulin insensitivity in 3T3-L1 adipocytes. Eur J Pharmacol 2010; 642: 47-55.

134 Martinez-Garcia C, Izquierdo-Lahuerta A, Vivas Y, Velasco I, Yeo TK, Chen $S$ et al. Renal lipotoxicity-associated inflammation and insulin resistance affects actin cytoskeleton organization in podocytes. PLoS ONE 2015; 10: e0142291.

135 Mayer CM, Belsham DD. Palmitate attenuates insulin signaling and induces endoplasmic reticulum stress and apoptosis in hypothalamic neurons: rescue of resistance and apoptosis through adenosine $5^{\prime}$ monophosphate-activated protein kinase activation. Endocrinology 2010; 151: 576-585.

136 Piro S, Maniscalchi ET, Monello A, Pandini G, Mascali LG, Rabuazzo AM et al. Palmitate affects insulin receptor phosphorylation and intracellular insulin signal in a pancreatic alpha-cell line. Endocrinology 2010; 151: 4197-4206.

137 Salvado L, Coll T, Gomez-Foix AM, Salmeron E, Barroso E, Palomer X et al. Oleate prevents saturated-fatty-acid-induced ER stress, inflammation and insulin resistance in skeletal muscle cells through an AMPK-dependent mechanism. Diabetologia 2013; 56: 1372-1382.

138 Kwon B, Lee HK, Querfurth HW. Oleate prevents palmitate-induced mitochondrial dysfunction, insulin resistance and inflammatory signaling in neuronal cells. Biochim Biophys Acta 2014; 1843: 1402-1413.

139 Perdomo L, Beneit N, Otero YF, Escribano O, Diaz-Castroverde S, Gomez-Hernandez A et al. Protective role of oleic acid against cardiovascular insulin resistance and in the early and late cellular atherosclerotic process. Cardiovasc Diabetol 2015; 14: 75.

140 Henriksen EJ, Diamond-Stanic MK, Marchionne EM. Oxidative stress and the etiology of insulin resistance and type 2 diabetes. Free Radic Biol Med 2011; 51: 993-999.

141 Galadari S, Rahman A, Pallichankandy S, Galadari A, Thayyullathil F. Role of ceramide in diabetes mellitus: evidence and mechanisms. Lipids Health Dis 2013; 12: 98.

142 Sathyanarayana P, Barthwal MK, Kundu CN, Lane ME, Bergmann A, Tzivion $\mathrm{G}$ et al. Activation of the Drosophila MLK by ceramide reveals TNF-alpha and ceramide as agonists of mammalian MLK3. Mol Cell 2002; 10: 1527-1533. 
143 Lanner JT, Katz A, Tavi P, Sandstrom ME, Zhang SJ, Wretman C et al. The role of $\mathrm{Ca} 2+$ influx for insulin-mediated glucose uptake in skeletal muscle. Diabetes 2006; 55: 2077-2083.

144 Whitehead JP, Molero JC, Clark S, Martin S, Meneilly G, James DE. The role of $\mathrm{Ca} 2+$ in insulin-stimulated glucose transport in 3T3-L1 cells. J Biol Chem 2001; 276: 27816-27824.

145 Furuta A, Tanaka M, Omata W, Nagasawa M, Kojima I, Shibata H. Microtubule disruption with BAPTA and dimethyl BAPTA by a calcium chelation-independent mechanism in 3T3-L1 adipocytes. Endocr J 2009; 56: 235-243.

146 Contreras-Ferrat A, Llanos P, Vasquez C, Espinosa A, Osorio-Fuentealba C, Arias-Calderon $\mathrm{M}$ et al. Insulin elicits a ROS-activated and an IP(3)dependent $\mathrm{Ca}(2)(+)$ release, which both impinge on GLUT4 translocation. J Cell Sci 2014; 127(Pt 9): 1911-1923.

147 Taddeo EP, Laker RC, Breen DS, Akhtar YN, Kenwood BM, Liao JA et al. Opening of the mitochondrial permeability transition pore links mitochondrial dysfunction to insulin resistance in skeletal muscle. Mol Metab 2014; 3: 124-134.

148 Wang $\mathrm{CH}$, Tsai TF, Wei YH. Role of mitochondrial dysfunction and dysregulation of $\mathrm{Ca}(2+)$ homeostasis in insulin insensitivity of mammalian cells. Ann NY Acad Sci 2015; 1350: 66-76.

149 Brownlee M. Biochemistry and molecular cell biology of diabetic complications. Nature 2001; 414: 813-820.

150 Shah A, Xia L, Goldberg H, Lee KW, Quaggin SE, Fantus IG. Thioredoxin-interacting protein mediates high glucose-induced reactive oxygen species generation by mitochondria and the NADPH oxidase, Nox4, in mesangial cells. J Biol Chem 2013; 288: 6835-6848.

151 Manea A, Manea SA, Todirita A, Albulescu IC, Raicu M, Sasson S et al. High-glucose-increased expression and activation of NADPH oxidase in human vascular smooth muscle cells is mediated by 4-hydroxynonenalactivated PPARalpha and PPARbeta/delta. Cell Tissue Res 2015; 361: 593-604.
152 Cheng DW, Jiang Y, Shalev A, Kowluru R, Crook ED, Singh LP. An analysis of high glucose and glucosamine-induced gene expression and oxidative stress in renal mesangial cells. Arch Physiol Biochem 2006; 112: 189-218.

153 Daiber A. Redox signaling (cross-talk) from and to mitochondria involves mitochondrial pores and reactive oxygen species. Biochim Biophys Acta 2010; 1797: 897-906.

154 Kumar B, Kowluru A, Kowluru RA. Lipotoxicity augments glucotoxicity-induced mitochondrial damage in the development of diabetic retinopathy. Invest Ophthalmol Vis Sci 2015; 56: 2985-2992.

155 Hong OK, Yoo SJ, Son JW, Kim MK, Baek KH, Song KH et al. High glucose and palmitate increases bone morphogenic protein 4 expression in human endothelial cells. Korean J Physiol Pharmacol 2016; 20: 169-175.

156 Lennon R, Pons D, Sabin MA, Wei C, Shield JP, Coward RJ et al. Saturated fatty acids induce insulin resistance in human podocytes: implications for diabetic nephropathy. Nephrol Dial Transplant 2009; 24: 3288-3296.

157 Shikama Y, Kudo Y, Ishimaru N, Funaki M. Possible Involvement of Palmitate in Pathogenesis of Periodontitis. J Cell Physiol 2015; 230: 2981-2989.

This work is licensed under a Creative Commons Attribution-NonCommercial-ShareAlike $\quad \mathbf{4 . 0}$ International License. The images or other third party material in this article are included in the article's Creative Commons license, unless indicated otherwise in the credit line; if the material is not included under the Creative Commons license, users will need to obtain permission from the license holder to reproduce the material. To view a copy of this license, visit http://creativecommons.org/licenses/by-nc-sa/4.0/ 